\title{
Mindfulness Based Stress Reduction (MBSR) dan Psychological Capital Intervention (PCI) untuk Mengurangi Burnout pada Perawat Lansia
}

\author{
Mindfulness Based Stress Reduction (MBSR) and \\ Psychological Capital Intervention (PCI) to Decrease \\ Burnout for Elderly Caregiver
}

\author{
Josephine Indah Setyawati, Yudiana Ratnasari \\ Fakultas Psikologi Universitas Indonesia \\ Email: josephineindah@gmail.com
}

\begin{abstract}
KATA KUNCI Burnout, Mindfulness Based Stress Reduction, Perawat Lansia, Psychological Capital Intervention,.
\end{abstract}

KEYWORDS Burnout, Elderly Caregiver, Mindfulness Based Stress Reduction, Psychological Capital Intervention.

ABSTRAK Perawat lansia yang bekerja di panti werdha sangat rentan mengalami burnout sehingga dapat memengaruhi penurunan performa kerja. Salah satu intervensi yang dapat digunakan untuk membantu mengatasi stress, menurunkan tingkat burnout dan mengantisipasi terjadinya burnout yaitu Mindfulness-Based Stress Reduction (MBSR) menggunakan pendekatan mindfulness, peserta diajak untuk menyadari situasi diri sini dan kini. Untuk mengantisipasi terjadinya burnout, penting juga untuk mengembangkan psychological capital (PsyCap), karakteristik positif yang dapat melindungi diri saat menghadapi situasi sulit, terutama aspek harapan dan optimisme. Peserta yang mengikuti intervensi ini yaitu delapan perawat lansia di Panti Werdha M di Jakarta Utara yang sudah bekerja selama minimal satu tahun. Pemilihan peserta didasari dari skor burnout yang lebih dari ratarata populasi perawat di panti tersebut dengan menggunakan instrumen Caregiver Burnout dan mengalami penurunan performa kerja berdasarkan evaluasi kinerja. Intervensi yang dilakukan terdiri dari tiga sesi MBSR dan satu sesi PsyCap dengan durasi sekitar 120 menit setiap sesi. Sesi follow-up dilakukan dua minggu setelah intervensi. Data kuantitatif dan kualitatif menunjukkan adanya penurunan tingkat burnout, meski dimensi personal accomplishment tidak menunjukkan perubahan signifikan. Penelitian ini merekomendasikan MBSR dan PCI sebagai intervensi yang cukup efektif untuk menurunkan tingkat burnout bagi perawat lansia. 
ABSTRACT Caregivers who work in nursing home are vulnerable to burnout which can affect work performance decline. One of the interventions that can be used to help cope with stress, reduce burnout levels and anticipate burnout is Mindfulness-Based Stress Reduction (MBSR) using a mindfulness approach, participants are invited to be aware of their current and present situation. To anticipate burnout, it is also important to develop psychological capital (PsyCap), positive characteristics that can protect oneself when facing difficult situations, especially aspects of hope and optimism. Participants who took part in this intervention were eight caregivers at the " $M$ " Nursing Home in North Jakarta who had worked for at least 1 year. The selection of participants was based on a burnout score that was more than the average nurse population at the home using the Caregiver Burnout instrument and decreased work performance based on performance evaluation. The intervention consisted of three MBSR sessions and one PsyCap session with a duration of about 120 minutes per session. A follow-up session was conducted two weeks after the intervention. Both quantitative and qualitative data show a decrease in the level of burnout, although the personal accomplishment dimension does not show a significant change. This research suggests that MBSR and PCI as effective interventions to reduce burnout rates for elderly caregivers.

\section{PENDAHULUAN}

Caregiver atau perawat merupakan individu yang memiliki peran memberikan perawatan kepada anak-anak, lansia, atau individu yang sedang mengalami penyakit kronis (Merriam Webster, dalam Hunt, 2003). Kasuya (dalam Widyanti \& Bintari, 2010) mengelompokkan caregiver menjadi formal dan informal. Pada intervensi kelompok ini, caregiver yang dimaksud yaitu formal caregiver, tenaga profesional yang dibayar untuk melakukan perawatan seperti di panti werdha. Di panti werdha, seorang perawat lansia berperan untuk memberikan perawatan untuk hampir 90\% kebutuhan lansia yang beragam (Waxman, Carner, \& Berkenstock, 1984) dan berperan menjadi sumber interaksi sosial bagi lansia yang dirawat, memenuhi kebutuhan kedekatan secara personal dan emosional kepada lansia (Chung, 2010; Waxman dkk., 1984). Pada saat bekerja, hubungan dan interaksi antara perawat dan orang yang dirawat dapat dipengaruhi dengan masalah atau penyakit yang dialami oleh lansia baik secara fisik, sosial, dan psikologis. Keluhankeluhan lansia ini juga sering disertai dengan munculnya emosi-emosi negatif, seperti putus asa, malu, takut, dan marah. Solusi terhadap masalah klien sering kali sulit dan membingungkan bagi perawat. Jika kondisi ini terjadi secara terus menerus, maka dapat menyebabkan perawat lansia mengalami kelelahan secara emosional hingga mengalami burnout (Maslach, Jackson, \& Leiter, 1997).

Berdasarkan wawancara kepada beberapa perawat dan observasi di sebuah panti werdha di Jakarta Utara, diketahui bahwa interaksi yang intens dengan para lansia menjadi salah satu sumber stress. Terutama saat lansia mulai bersikap kasar dengan mengumpat atau membentak perawat. Sumber stress lain yaitu sikap lansia yang sulit diatur dan menolak untuk diurus oleh perawat tertentu. Sebagai perawat, mereka dituntut untuk tetap sabar menghadapi lansia dan terdapat aturan yang ketat terkait perilaku kasar yang disengaja maupun tidak terhadap lansia yang menjadi penghuni panti. Tuntutan ini membuat perawat terkadang menjadi tertekan dengan sikap para lansia yang kurang menyenangkan. Bahkan terdapat beberapa perawat yang kehilangan kesabaran, dan balik membentak lansia, meski sudah 
dilarang oleh aturan di panti. Sumber stress lain yang juga memengaruhi para perawat yaitu masalah hubungan personal seperti masalah keluarga, yang berdampak pada performa kerja yang juga kurang maksimal dan masalah hubungan dengan senior ate rekan kerja. Selain itu, pekerjaan merawat lansia yang non mandiri menjadi tantangan tersendiri bagi perawat di panti ini. Menurut mereka, berbagai tugas untuk merawat lansia ini cukup berat tanggung jawabnya, mulai dari memandikan, menyuapi, memberi obat, hingga memenuhi kebutuhan sosial para lansia dengan mengajak bicara. Berbagai tugas yang berat ini seringkali menimbulkan kelelahan bagi perawat, hingga ada yang sampai membuat mereka merasa stress akan pekerjaannya, tetapi tidak tahu bagaimana cara mengatasnya.

Stressor yang dialami oleh perawat jika terus menerus dirasakan dan tidak diatasi, maka dapat mengarah pada kondisi burnout. Peng dkk. (2013) menyatakan bahwa job burnout merupakan kondisi kelelahan fisik dan mental yang disebabkan oleh beban kerja yang tinggi dan kondisi stress yang dialami. Burnout ini juga dikenal sebagai sindrom psikologis yang ditandai dengan kondisi kelelahan secara emosional, depersonalisasi, dan penurunan performa kerja yang sangat mungkin dialami oleh orang-orang yang banyak bekerja bersama orang lain (Maslach dkk., 1997). Kondisi ini sangat mungkin terjadi pada orang-orang yang bekerja di bidang jasa pelayanan yang memiliki jangka waktu kerja yang lama, beban kerja yang berat, dan intensitas kerja tinggi (Freudenberger, dalam Peng dkk., 2013). Penelitian juga menunjukkan bahwa perawat memiliki prevalensi yang tergolong tinggi untuk mengalami burnout dan 50\% dari perawat dalam bangsal lansia mengalami burnout (Cocco, Gatti, de Mendonça Lima, \& Camus 2003). Sindrom psikologis ini tidak muncul tiba-tiba, tetapi merupakan hasil dari proses pekerjaan yang stressful dalam waktu yang lama (Iacovides, Fountoulakis, Kaprinis, \& Kaprinis, 2003).

Di panti werdha, perawat merasakan stressor pekerjaan berupa beban kerja, hubungannya dengan lansia, dan juga hubungannya dengan perawat lain. Maslach dan Jackson (dalam Peng dkk., 2013) mengungkapkan bahwa paparan stressor emosional dan interpersonal di tempat kerja yang terus menerus dan dalam waktu lama dapat membuat individu mengalami burnout. Burnout pada perawat lansia dapat disebabkan oleh banyaknya hal yang harus dilakukan untuk membantu lansia memenuhi kebutuhannya sehari-hari (Okoye \& Asa, 2011). Merawat lansia menuntut pengorbanan yang besar, baik fisik maupun emosional (Okoye \& Asa, 2011). Perawat biasanya mengabdikan diri untuk memenuhi kebutuhan orang lain tetapi cenderung mengabaikan kebutuhan diri mereka sendiri. Mereka cenderung tidak mengenali tandatanda kelelahan, stres, hingga burnout yang mereka alami (Okoye \& Asa, 2011).

Kondisi burnout pada perawat ini memiliki berbagai dampak negatif, antara lain sering absen dari pekerjaan, menghindar dari pekerjaan, depresi, dan resiko bunuh diri (Dyrbye dkk.; Piers dkk., McGilton dkk., dalam Kandelma dkk., 2018). Tidak hanya berdampak negatif pada kondisi psikologis perawat, tetapi juga memengaruhi kualitas perawatan dan meningkatkan taraf mortalitas individu yang dirawat (Wallace dkk., dalam Kandelman Mazars, \& Levy, 2018). Terutama pada perawat bagi lansia, kondisi burnout dapat berpengaruh kepada sikap perawat yang tidak menghiraukan dan melakukan kekerasan kepada lansia (Bužgová \& Ivanová; McDonald dkk., dalam Kandelman dkk., 2018).

Berangkat dari fenomena tersebut, maka penelitian ini menjadi penting dilakukan untuk melihat efektivitas dari pemberian intervensi untuk menurunkan burnout pada perawat lansia. Dari hasil penelitian juga dapat menjadi rekomendasi bagi pihak panti untuk memberikan intervensi yang tepat bagi perawat lansia agar terhindar dari burnout yang dapat memengaruhi performanya saat bekerja, salah satunya dapat membahayakan lansia yang dirawat. 
Terkait dengan intervensi untuk burnout, terdapat beberapa teknik untuk mengurangi burnout, antara lain cognitive behavioral therapy (CBT) yang berfokus untuk memperkuat resiliensi fisik dan psikologis, stress inoculation therapy (SIT), mindfulness yang melatih kesadaran dan atensi here and now, dan pendekatan secara organisasional (Leiter \& Maslach, 2014). Dari berbagai teknik tersebut, pendekatan mindfulness dengan Mindfulness Based Stress Reduction dari Jon Kabat-Zinn paling banyak dipakai untuk populasi tenaga kesehatan dan berbagai penelitian menunjukkan bahwa ketika teknik ini diberikan pada tenaga kesehatan dan pekerja sosial, maka dapat menurunkan tingkat burnout. Terutama pada dimensi emotional exhaustion dengan latihan relaksasi, dan dimensi depersonalisasi melalui latihan memberi jarak dan tidak memberikan judgement (Leiter \& Maslach, 2014). MBSR ini merupakan intervensi yang disusun secara sistematis berdasarkan meditasi mindfulness yang fokus pada pikiran dan perasaan negatif pada diri, untuk mengurangi stress dan keluhan fisik (Grossman, Niemann, Schmidt, \& Walach, 2004). Mindfulness mendorong individu untuk memberikan perhatian pada kondisi mental yang dirasakan saat ini tanpa memberikan penilaian terhadap kondisi mental yang dialami tersebut (Grossman dkk., 2004). Teknik ini dapat disesuaikan secara fleksibel terhadap populasi tertentu. Penelitian terhadap pekerja layanan kesehatan juga menunjukkan bahwa MBSR mampu membantu perawat untuk mengurangi burnout (Shapiro, Brown, \& Biegel, 2007). Begitu pula dengan penelitian yang dilakukan di panti werdha lain di Jakarta, pemberian MBSR ini disinyalir dapat membantu menurunkan tingkat burnout, terutama dalam mengurangi depersonaliasi dan meningkatkan perasaan pencapaian diri (Adinda \& Bintari, 2020).

Selain menurunkan tingkat burnout menggunakan MBSR, penting untuk melatih perawat mengembangkan karakter positif pada dirinya untuk mencegah burnout terjadi kembali. Secara spesifik, karakter positif tersebut dikenal sebagai Psychological Capital (PsyCap). PsyCap merupakan sebuah keadaan individu yang dapat berpikir positif, muncul seiring perkembangan diri individu (Luthans dkk., dalam Peng dkk., 2013). PsyCap terdiri dari empat aspek, yaitu efikasi diri, optimisme, harapan, dan resiliensi (Luthans, Youssef, \& Avolio, 2007). Laschinger dan Fida (2014) mengemukakan bahwa PsyCap memiliki peran sebagai faktor protektif bagi seorang perawat dalam menghadapi stressor yang timbul di dalam pekerjaan. Kualitas PsyCap pada diri individu akan membantu mengatasi stressor, menurunkan tingkat burnout, dan selanjutnya dapat meningkatkan kualitas performa kerja (Luthans dkk., dalam Peng dkk., 2013). PsyCap juga menjadi mediator antara praktik mindfulness dengan psychological well-being. Individu yang mindful dapat bersikap lebih fleksibel dan tidak impulsif saat menghadapi situasi yang menantang ketika dipadukan dengan adanya PsyCap. Khususnya pada aspek harapan dan optimisme, ketika seseorang sudah belajar untuk menjadi mindful dan dapat memberikan jarak dari reaksi kognitif dan emosinya, maka ia akan menjadi individu yang lebih punya harapan dan bersikap lebih optimis (Malinowski \& Lim, 2015).

Secara khusus, yang akan dibahas pada intervensi kelompok ini yaitu harapan dan optimisme sebagai faktor psikologi positif yang juga memengaruhi penurunan tingkat burnout dalam pekerjaan. Harapan merupakan kondisi motivasional positif individu yang terdiri atas agency (determinasi untuk memulai dan menjaga usaha dalam mencapai sebuah tujuan) dan pathways (waypower atau keyakinan akan kemampuan diri untuk secara sukses mengimplementasikan rencana dan juga alternatif saat dalam kesulitan demi mencapai tujuan) (Luthans \& Jensen, 2002). Hasil penelitian Snyder (2000) menjelaskan bahwa harapan merupakan kondisi kognitif atau pikiran seseorang dimana individu tersebut mampu membuat tujuan yang realistis tapi juga menantang. Terdapat 
ekspektasi tertentu dalam tujuan dan dalam mencapainya dilakukan dengan determinasi diri, berenergi, dan dengan adanya persepsi mengenai kontrol internal diri. Individu yang memiliki harapan lebih akan memiliki tujuan kerja yang jelas, mampu merencanakan hal-hal yang akan dilakukan untuk mencapai tujuan dan mau bekerja keras, serta kecil kemungkinan untuk mengalami burnout (Peng dkk., 2013). Bagi seorang perawat, penting untuk memiliki harapan agar dapat mempertahankan keyakinan diri, keteguhan hati, kemauan untuk mengejar tujuan, dan tidak mengelak saat mengatasi tekanan dalam pekerjaan (Sherwin, Elliott, Rybarczyk, Frank, Hanson, \& Hoffman, 1992)

Dimensi lain yaitu optimisme. Luthans dkk. (2007) menerangkan bahwa optimisme berperan dalam kejadian positif di kehidupan seseorang. Orang dengan optimisme melihat penyebab dari kejadian yang diinginkan sebagai suatu hal yang bisa dikendalikan. Mereka akan terus berekspektasi bahwa penyebab dan kejadian ini terus terjadi dikemudian hari dan dapat menjadi suatu hal bermanfaat dalam mengendalikan hal lainnya nantinya. Penjelasan positif mereka mengenai suatu hal ini membuat mereka mampu melihat secara positif dan mampu menginternalisasi aspek baik dalam hidupnya tidak hanya di masa lalu, masa sekarang, tapi juga masa yang akan datang (Seligman, dalam Hansen, Buitendach, \& Kanengoni 2015). Untuk profesi sebagai seorang perawat lansia di panti werdha, adanya optimisme membantu mereka untuk mengurangi tingkat stress karena dapat membuat atribusi positif pada berbagai peristiwa, menunjukkan sikap yang positif, dan dapat lebih mudah mengatasi berbagai macam bentuk stressor pekerjaan (Riolli \& Savicki; Chang dkk., dalam Peng dkk., 2013).

Terkait dengan peningkatan PsyCap, dapat dilakukan intervensi dengan pendekatan Psychological Capital Intervention (PCI). PCI ini merupakan intervensi yang langsung menyasar kepada masing-masing dimensi dari PsyCap, dengan terdapat tujuan untuk masingmasing dimensi. Untuk dimensi harapan, PCI berfokus pada pembuatan tujuan, langkah yang harus ditempuh, dan apa yang harus dilakukan untuk mengatasi hambatan untuk pencapaian tujuan (Luthans, Avey, Avolio, Norman, \& Combs, 2006). Latihan untuk meningkatkan harapan dapat berpengaruh pada peningkatan optimisme seseorang (Luthans dkk., 2006). Diharapkan dengan meningkatnya harapan dan optimisme, akan membantu perawat lansia untuk menurunkan tingkat burnout dalam pekerjaannya dan sebagai faktor protektif yang dapat mengurangi resiko terjadinya burnout.

Berdasarkan berbagai pemaparan tersebut di atas, maka pertanyaan pada penelitian ini yaitu apakah pemberian intervensi MBSR dan PsyCap, terutama pada aspek harapan dan optimisme, efektif untuk menurunkan tingkat burnout pada perawat lansia di Panti Werdha M?

\section{METODE PENELITIAN \\ Desain}

Desain penelitian ini yaitu quasiexperimental one-group. Pengukuran dilakukan sebanyak tiga kali, yaitu pre-test, post-test, dan follow-up setelah dua minggu sesi intervensi selesai diberikan. Intervensi diberikan sebanyak empat sesi dengan durasi sekitar 120 menit per sesi. Selain itu juga dilakukan unstructured interview untuk mendapatkan data kualitatif dari peserta.

\section{Partisipan}

Penelitian dilakukan pada delapan perawat lansia yang bekerja di Panti Werdha M di Jakarta Utara. Perawat yang partisipan merupakan rekomendasi dari kepala perawat di panti tersebut berdasarkan hasil evaluasi kinerja yang menunjukkan penurunan performa kerja dan skor setiap dimensi burnout di atas rata-rata populasi perawat lansia di panti tersebut. Selain itu, kriteria lain adalah perawat yang sudah bekerja minimal selama enam bulan. 


\section{Setting dan Peralatan}

Kegiatan intervensi dilakukan di aula Panti Werdha M di Jakarta Utara. Peralatan yang digunakan yaitu modul intervensi dan presentasi power point berisi materi.

\section{Prosedur}

Penjaringan partisipan dilakukan dengan cara memberikan pengukuran Caregiver Burnout pada semua perawat lansia di Panti Werdha M untuk menentukan peserta intervensi kelompok yang didasari oleh skor burnout yang masuk dalam kategori sedang-tinggi dan mengalami indikasi penurunan performa menurut kepala perawat yang memberikan evaluasi kinerja. Pada saat pemberian pengukuran burnout, semua diberikan informed consent kesediaan untuk menjalani terapi kelompok apabila terpilih untuk menjadi peserta. Dari proses tersebut, didapat delapan orang yang dipilih dan bersedia mengikuti terapi kelompok.

Pelaksanaan intervensi kelompok dilakukan tiga bulan setelah dilakukan skrining karena sempat terkendala pandemi Covid-19 sehingga intervensi harus ditunda. Intervensi kelompok dilaksanakan sebanyak empat sesi, yaitu tiga sesi MBSR dan satu sesi PCI dengan pemberian psikoedukasi mengenai aspek harapan dan optimisme.

\section{Instrumen}

Alat ukur yang digunakan dalam penelitian ini yaitu Caregiver Burnout (CABUT) yang dirancang berdasarkan teori burnout yang dikemukakan oleh Maslach dan Leiter (2016) dan sudah disesuaikan dengan kondisi perawat panti werdha di Jabodetabek. Uji reliabilitas pada alat ukur ini menghasilkan koefisien reliabilitas sebesar 0,85 pada dimensi exhaustion, 0,81 pada dimensi depersonalization, dan 0,6 pada dimensi reduced personal accomplishment. Reliabilitas pada dimensi reduced personal accomplishment memang paling rendah dan aitem-aitemnya berpotensi tidak konsisten secara internal, tetapi hal ini pun juga sejalan dengan penelitian-penelitian terdahulu bahwa dimensi ini memang memiliki nilai korelasi yang rendah dan terkadang tidak signifikan dengan dua dimensi lainnya (Cordes, Dougherty, \& Blum, 1997; Lee \& Ashforth, 1990).

Alat ukur ini terdiri dari 15 aitem untuk tiga dimensi burnout, yaitu emotional exhaustion, depersonalization, dan reduced personal accomplishment. Skor setiap aitem menggunakan skala likert, 0-5, dengan pilihan jawaban tidak pernah, jarang, kadang-kadang, cukup sering, sering, dan selalu. Pengukuran burnout ini dilakukan sebanyak tiga kali, yaitu pre-test sebelum intervensi kelompok diberikan pada awal sesi pertama, post-test diberikan tepat setelah intervensi kelompok berakhir pada akhir sesi ketiga MBSR, dan follow-up setelah dua minggu intervensi diberikan. PsyCap pada intervensi ini diukur menggunakan kuesioner untuk mengukur pemahaman peserta terkait materi setiap aspek PsyCap atau pada penelitian ini spesifik pada aspek harapan dan optimisme. Terdapat 5 aitem dengan 4 pilihan jawaban untuk masing-masing aspek yang diukur. Pengukuran ini dilaksanakan sebanyak tiga kali, yaitu pre-test sebelum intervensi diberikan, post-test setelah intervensi, dan follow-up setelah dua minggu intervensi berakhir.

Efektivitas dari intervensi dilihat melalui penurunan skor CABUT dari masing-masing peserta sejak hasil pre-test, post-test, dan follow-up. Selain itu juga diketahui secara kualitatif melalui wawancara kepada peserta setelah intervensi slesai dilakukan.

\section{Rancangan Program Intervensi}

Program intervensi dibagi menjadi empat sesi yang masing-masing sesinya berlangsung selama kurang lebih 120 menit. Intervensi terdiri dari intervensi berbasis MBSR sebanyak tiga sesi, dan satu sesi terakhir berisi psikoedukasi tentang PsyCap, terutama aspek harapan dan optimisme sebagai kualitas positif yang dapat menjadi penguat bagi peserta dalam meminimalisir burnout ketika bekerja. 
Sesi pertama peserta diajak untuk berbagi pengalamannya selama bekerja di panti werdha terkait pengalaman yang membuat mereka merasa tertekan dan kesulitan yang dihadapi selama bekerja sebagai perawat lansia, sehingga dapat membangun kepercayaan kelompok. Pada sesi pertama, lebih banyak ditekankan mengenai psikoedukasi terkait dengan kondisi stress, stressor, burnout, dan pengenalan mengenai Mindfulness-Based Stress Reduction (MBSR) dan dampaknya terhadap penurunan stress selama bekerja. Pada sesi ini, peserta juga mencoba mindful check-in dan latihan abdominal breathing untuk memerhatikan kondisinya sini dan kini. Pada sesi pertama ini, diharapkan peserta mampu memahami definisi stress, stressor, dan mengenali kondisi tubuhnya saat mengalami stress, dan memahami bahwa MBSR ini pun juga dapat diterapkan secara sederhana dalam kehidupan seharihari.

Sesi kedua berfokus pada pengenalan ke dalam diri. Peserta mencoba body-scan meditation untuk latihan memerhatikan sensasi ketubuhan, terutama ketika dalam kondisi stress lalu peserta akan diminta untuk mengidentifikasi sensasi ketubuhan itu. Pada sesi kedua ini, peserta juga diberikan psikoedukasi mengenai selfcare dan diajak untuk berdiskusi mengenai alternatif self-care yang dapat dilakukan. Melalui sesi kedua ini, partisipan diharapkan mampu menyadari sensasi ketubuhan yang dirasakan sebagai identifikasi awal saat mereka mengalami stress.

Sesi ketiga berisi penjelasan peran persepsi dalam hubungan antara stimulus dan respon. Melalui penjelasan ini, peserta diharapkan dapat memahami bahwa persepsi dapat memengaruhi respon individu yang berbeda-beda terhadap stimulus yang sama. Agar peserta semakin memahami kaitan antara stimulus, persepsi, dan respon ini, akan diberikan studi kasus sebagai visualisasi. Pada sesi ini peserta juga diajak untuk mencoba love and kindness meditation untuk membantu partisipan menyadari cinta kasih yang ada dalam dirinya dan mengembangkan cinta kasih tersebut kepada lingkungan dan dalam menghadapi stressor di pekerjaannya.

Sesi keempat dikhususkan untuk intervensi psychological capital, terutama tentang harapan dan optimisme. Sesi ini terdiri dari psikoedukasi mengenai harapan dan optimisme sebagai kualitas positif yang dimiliki individu untuk dapat membentengi dirinya saat menghadapi situasi yang stressful. Pada sesi ini juga dilakukan meditasi mindfulness untuk membantu peserta melatih teknik mindfulness yang sebelumnya telah diberikan. Pada saat bagian harapan dijelaskan, peserta diajak untuk membuat SMART-Goal sebagai aplikasi dari harapan. Lalu saat menjelaskan tentang optimisme, peserta diajak untuk merefleksikan kembali pengalamannya selama bekerja di panti sebagai perawat lansia untuk melatih mengapresiasi diri dan menumbuhkan optimisme dalam diri mereka.

\section{Teknik Analisis Data}

Data dari hasil pemberian alat ukur diolah secara kuantitatif dalam bentuk deskriptif, untuk melihat penurunan skor sebelum intervensi, sesudah intervensi, dan setelah beberapa saat selesai intervensi. Selain itu juga dilakukan pengolahan data kualitatif yang didapat dari hasil sharing mendalam dari peserta selama sesi. Data kualitatif ini menjadi pendukung dari data kuantitatif.

\section{ANALISIS DAN HASIL \\ Hasil Kuantitatif}

Data demografi peserta menunjukkan delapan peserta bersuku Flores. Terdapat enam perempuan dan dua laki-laki yang menjadi peserta dengan rentang usia 18-27 tahun. Peserta merupakan perawat yang sudah bekerja selama minimal satu tahun dan paling lama tiga tahun 10 bulan dengan enam orang menjabat sebagai asisten perawat, dan dua orang dengan jabatan perawat. Tingkat pendidikan peserta minimal SMK Keperawatan sebanyak enam orang, satu orang dengan pendidikan 
terakhir D3 Keperawatan, dan satu orang dengan pendidikan terakhir S1 Keperawatan.

Setelah intervensi dilakukan, didapat bahwa secara umum data menunjukkan peserta merasakan perubahan yang lebih baik terkait kelelahan emosional dan sikap negatif dan menarik diri dari pekerjaannya setelah mengikuti terapi kelompok. Akan tetapi, penurunan produktivitas dan performa kerja masih tetap dirasakan oleh peserta meski telah diberikan intervensi.

Gambar 1

Grafik Perbandingan Skor Emotional Exhaustion

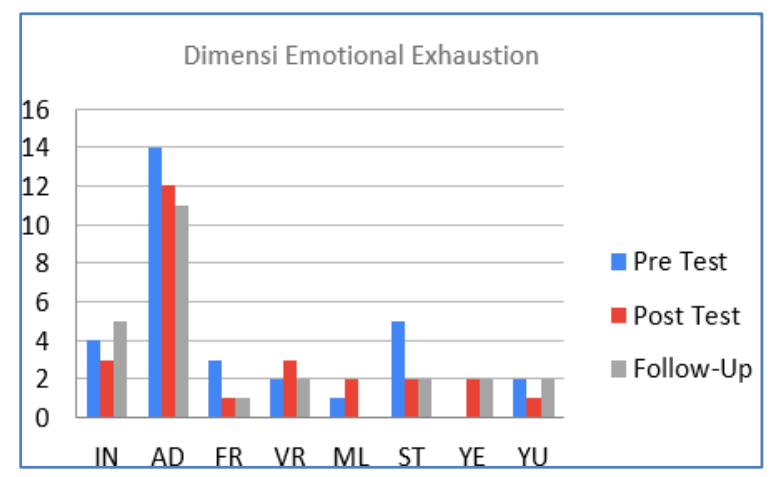

Gambar 2

Grafik Perbandingan Skor Depersonalization

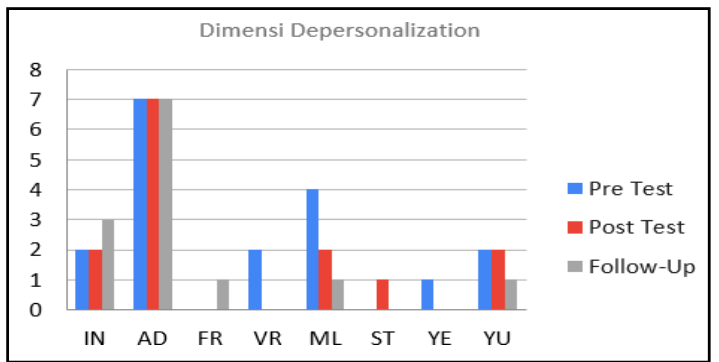

Gambar 3

Grafik Perbandingan Skor Personal Accomplishment

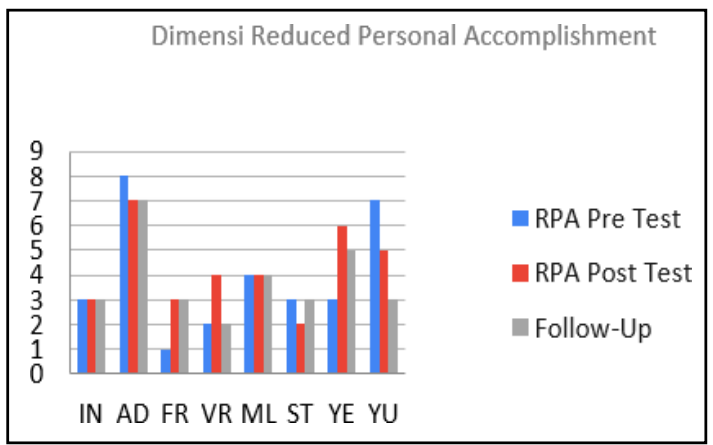


Terkait dengan dimensi emotional exhaustion, terdapat penurunan skor sebanyak 1-3 poin (Gambar 1). AD mendapat skor paling besar dibandingkan peserta lain, yaitu 14 yang menunjukkan bahwa ia merasakan kelelahan emosional yang paling besar dibandingkan dengan peserta lain. Tetapi angka ini turun dua poin setelah intervensi diberikan, sehingga skor AD pada dimensi ini tetap paling besar pada post-test dibandingkan dengan peserta lain. Penurunan skor paling besar terjadi pada ST, skor dimensi ini sebelum intervensi yaitu lima, dan turun tiga poin menjadi dua setelah ia selesai mengikuti intervensi, menunjukkan bahwa terapi ini memberi dampak paling besar baginya untuk dimensi ini. Pada peserta YE, justru terdapat peningkatan sebanyak dua poin, dari nol menjadi dua, yang menunjukkan bahwa setelah terapi kelompok selesai, ia justru merasakan tanda-tanda kelelahan emosional.

Pada dimensi depersonalization, secara umum tidak terdapat perubahan yang signifikan pada skor peserta sebelum diberikan intervensi dan sesudah intervensi, meski skor rata-ratanya menurun (Gambar 2). Skor paling tinggi pada dimensi ini sebelum intervensi yaitu $\mathrm{AD}$ dengan skor tujuh, dan tidak berubah setelah intervensi, hal ini menunjukkan bahwa sesudah intervensi diberikan, masih ada sikap negatif dan menarik diri yang sebelumnya dirasakan. Akan tetapi, pada peserta VR, ML, dan YE, terdapat penurunan skor setelah intervensi diberikan, menunjukkan bahwa kegiatan terapi kelompok mengurangi sikap negatif kecenderungan menarik diri saat bekerja sebagai perawat lansia. Selain itu, pada peserta ST, terdapat peningkatan skor sebanyak satu poin pasca intervensi, menunjukkan bahwa tanda adanya sikap negatif dan menarik diri dalam bekerja baru muncul sesudah intervensi diberikan.

Pada dimensi reduced personal accomplishment, secara umum terdapat perubahan skor sebesar 1-3 poin (Gambar 3).
Terdapat peserta yang mengalami penurunan skor, artinya terdapat peningkatan pada produktivitas dan performa kerja, tetapi secara umum peserta pada terapi kelompok ini mengalami peningkatan skor yang berarti penurunan produktivitas dan performa kerja saat bekerja merawat lansia semakin dirasakan.

Setelah dilakukan follow-up, secara umum terdapat perubahan yang lebih positif terkait kelelahan emosional, sikap negatif terhadap lansia yang dirawat, dan peningkatan produktivitas dan performa kerja.

Terkait dengan dimensi emotional exhaustion atau kelelahan emosional, skor follow-up tertinggi ditampilkan oleh $\mathrm{AD}$, terdapat penurunan satu skor dibandingkan saat post-test. Penurunan skor juga ditunjukkan oleh VR sebanyak satu poin, dan ML sebanyak dua poin. Penurunan ini menunjukkan bahwa setelah dua minggu kegiatan intervensi diadakan, kelelahan emosional yang sebelumnya dirasakan, sudah semakin berkurang. Sedangkan pada IN dan YU, justru terdapat peningkatan skor, yang menunjukkan bahwa setelah dua minggu kegiatan selesai dilakukan, kelelahan emosional ini semakin kuat dirasakan.

Selanjutnya pada dimensi depersonalization, skor follow-up tertinggi kembali ditampilkan oleh $\mathrm{AD}$, dengan tidak menunjukkan perubahan skor dibandingkan dengan post-test. Pada ML, ST, dan YU, terdapat penurunan skor sebanyak satu poin pada masing-masing peserta, menunjukkan bahwa ketiganya merasakan penurunan sikap negatif dan menghindar dari lansia yang dirawat setelah dua minggu sesi berakhir. Akan tetapi, pada FR dan IN, skornya justru meningkat sebanyak dua poin. Pada FR, skor post-test menunjukkan angka nol, dan setelah follow-up naik menjadi satu. Hal ini dapat mengindikasikan bahwa keduanya mengalami peningkatan sikap negatif saat berinteraksi dengan lansia 
yang dirawatnya selama dua minggu setelah kegiatan berakhir.

Terakhir yaitu dimensi reduced personal accomplishment, skor follow-up paling tinggi juga ditunjukkan oleh $\mathrm{AD}$, dan tidak berubah dari skor post-test. Setelah dua minggu kegiatan intervensi berakhir, IN, FR, dan ML, juga tidak mengalami perubahan. Penurunan skor dialami oleh VR, YE, dan YU, dengan penurunan skor paling banyak ditampakkan oleh VR dan YU sebanyak dua poin. Hal ini menunjukkan bahwa setelah dua minggu pasca intervensi, mereka mengalami peningkatan semangat kerja dan produktivitas yang lebih baik dibandingkan pada saat setelah intervensi berakhir. Berbeda dengan ST, skornya justru meningkat pada saat follow-up. Hal ini dapat menjadi indikasi bahwa setelah dua minggu kegiatan berakhir, ia justru mengalami penurunan produktivitas dan perfoma kerja dibandingkan dengan sesaat setelah intervensi berakhir.

Terkait dengan dimensi harapan dan optimisme, data didapat dari skor kuesioner dan self-rating.

\section{Gambar 4}

\section{Grafik Perbandingan Skor Pemahaman Materi Harapan}

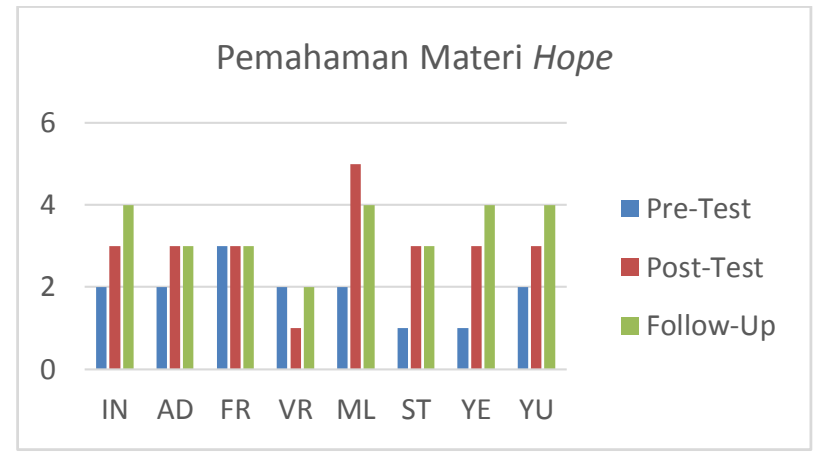

Gambar 5

Grafik Perbandingan Self-Rating Pemahaman Materi Harapan

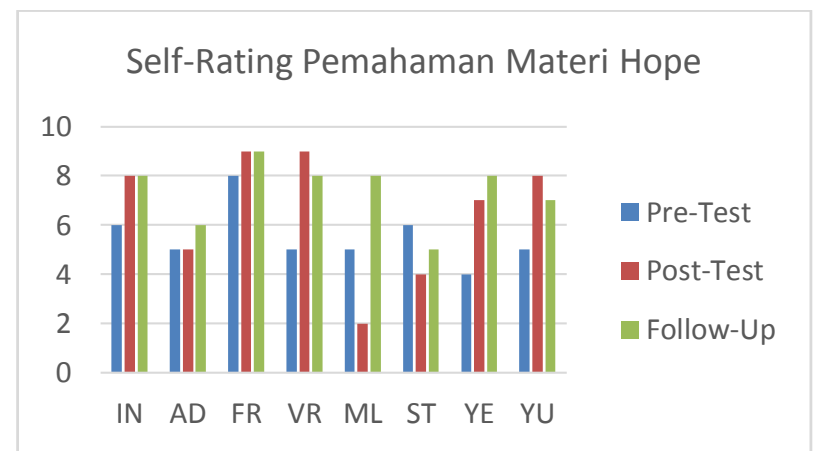


Gambar 6

Grafik Perbandingan Skor Pemahaman Materi Optimisme

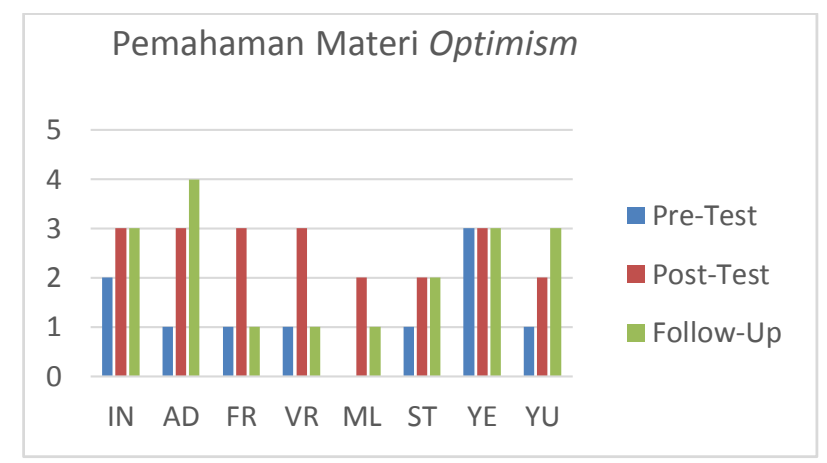

Gambar 7

Grafik Perbandingan Self-Rating Pemahaman Materi Optimisme

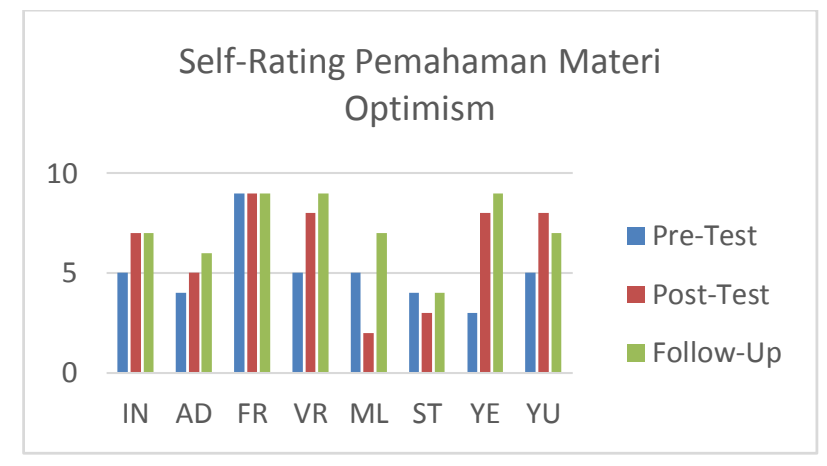

Berdasarkan tabel dan grafik perbandingan skor pemahaman materi dan self-rating terkait materi harapan, diketahui bahwa terdapat peningkatan skor rata-rata pemahaman peserta mengenai materi ini (Gambar 4), dibandingkan dari sebelum diberikan intervensi dan sesudah intervensi. Begitu pula skor rata-rata self-rating peserta (Gambar 5). Hal ini menunjukkan bahwa peserta mampu menangkap materi dengan baik dan terdapat tambahan pengetahuan mengenai materi ini bagi peserta, dan keyakinan peserta bahwa pengetahuan tentang materi ini juga meningkat. Pada hasil follow-up setelah dua minggu intervensi diberikan, skor rata-rata self-rating post-test dan follow-up secara umum mengalami peningkatan sebanyak satu poin, yang menjadi indikasi bahwa peserta merasa setelah dua minggu berakhir, mereka lebih memahami materi ini.

Lalu pada materi optimisme mengalami peningkatan setelah materi diberikan kepada peserta (Gambar 6). Hal ini dapat mengindikasikan bahwa setelah intervensi diberikan, pemahaman peserta menjadi bertambah. Begitu pula pada skor rata-rata self-rating atau skor subjektif peserta mengenai pemahamannya terkait materi yang mengalami peningkatan setelah dilakukan post-test (Gambar 7). Hal ini menunjukkan bahwa terdapat kesesuaian antara pendapat subjektif peserta bahwa mereka sudah memahami materi dan dibuktikan melalui peningkatan skor saat diberikan pertanyaan seputar materi setelah intervensi. Lalu pada hasil follow up, diketahui bahwa terdapat penurunan skor 
rata-rata pemahaman materi optimisme yang dilihat dari hasil skor kuesioner yang berisi pertanyaan seputar materi ini. Akan tetapi, secara subjektif, secara umum peserta merasa lebih memahami materi tentang optimisme ini setelah terdapat jeda dua minggu pasca kegiatan intervensi berakhir.

\section{Hasil Kualitatif}

\section{a. IN}

Setelah mengikuti terapi kelompok, IN menjadi tahu bagaimana harus merespon situasi yang dianggap sulit dan memunculkan emosi negatif. Melalui terapi kelompok ini, IN juga menyadari ada cara self-care yang dianggap cocok bagi dirinya. Terapi kelompok ini juga membuat IN merasa lebih mengenal stress yang ia rasakan, dan mendapat pemahaman bahwa kondisi stress juga dapat dirasakan oleh rekan lainnya. IN mendapat tilikan bahwa perasaan senang dan bahagia dapat muncul bersamaan dengan perasaan sedih. Ia juga belajar untuk menggunakan hal-hal yang ia miliki seperti ingatan yang menyenangkan untuk membantunya bersikap lebih positif dalam bekerja.

\section{b. AD}

Setelah mengikuti terapi kelompok, AD merasa bahwa stress merupakan kondisi yang wajar. Ia juga menjadi merasa lebih nyaman dalam bekerja, rileks dalam menghadapi situasi dan mencoba melatihkan teknik-teknik mindfulness yang sudah diajarkan. Bagi AD, berbagai teknik mindfulness sederhana yang dapat dilakukan pada keseharian dapat membantunya untuk berperilaku secara sadar meski menghadapi masalah. Ketika ia menemui masalah saat bekerja, ia dapat mencoba untuk mengambil jarak dengan mencoba keluar sejenak dari situasi itu untuk menenangkan diri atau dapat meminta bantuan dari rekan lain. Terkait dengan sesi harapan dan optimisme, AD mengungkapkan menjadi lebih bersemangat karena menjadi sadar bahwa banyak jalan menuju kesuksesannya, pekerjaan sebagai perawat saat ini dapat dijadikan sebagai salah satu cara untuk mencapai tujuannya yang lebih besar.

\section{c. FR}

Melalui terapi kelompok, FR mengungkapkan bahwa ia menjadi tahu definisi stress, eustress, dan menyadari apa saja sumber stressnya selama ini. FR juga mengetahui peran persepsi pada respon stressnya. Ia juga mendapat tilikan bahwa latihan abdominal breathing dapat diaplikasikan untuk membuat dirinya merasa lebih nyaman ketika menemui situasi yang menekan, begitu pula latihan meditasi yang dapat membantunya memunculkan perasaan rileks. Ketika menghadapi situasi yang dianggap menekan, ia dapat mengatasinya dengan meminta tolong asisten perawat. Selain itu, ia merasa perlu menanamkan persepsi "tantangan" saat menghadapi kesulitan.

\section{d. VR}

Melalui terapi kelompok, VR juga mendapat tilikan bahwa ada cara yang lebih positif untuk mengatasi stress, misalnya mengambil jeda dengan bernafas. VR juga mendapat masukan dari teman-temannya untuk mengurangi kebiasaannya menyendiri sebagai self-carenya selama ini, karena justru membuatnya hanya menghindar dari masalah, tidak menyelesaikannya. VR juga mengungkapkan bahwa ia mendapat pengalaman baru setelah latihan body-scan meditation, ia menjadi sadar situasi tubuhnya yang terasa tidak nyaman saat mengalami stress. Ia juga merasa lebih tenang saat memikirkan momen saat ini dan saat latihan love and kindness meditation.

\section{e. ML}

ML juga mendapat tilikan bahwa penting untuk berperilaku secara sadar, dan menyadari ketika ia merasa stress, ia tidak benar-benar sadar akan perilaku yang ia lakukan. Setelah mengikuti terapi kelompok, ia terbantu untuk menyadari definisi stress dan bagaimana menanganinya, salah satunya dengan latihan mindfulness untuk membuatnya lebih santai, dan dengan 
melakukan self-care yang tepat. Ia juga belajar untuk mencari alternatif cara menangani situasi yang menekan yaitu dengan mencari bantuan dari orang lain, dan meminta motivasi dari rekan kerjanya. ML juga memberikan kesan setelah sesi PsyCap, terutama sesi harapan dan optimisme, ia menyadari bahwa setiap kesulitan yang dialami sebagai perawat lansia pasti ada jalan keluarnya dan banyak jalan untuk menyelesaikan kesulitan itu.

\section{f. ST}

Setelah mengikuti terapi kelompok, ST mengungkapkan bahwa merasa lebih nyaman dan tenang. Ia menjadi tahu apa itu stress dan sumber stress yang ia alami. ST merasa latihan mindfulness bermanfaat baginya karena membantunya merasa lebih rileks, terutama saat latihan mindful checkin. Ia mengakui bahwa saat latihan pertama kali, punggungnya terasa sakit, tetapi karena ia anggap latihan ini bermanfaat, maka ia juga mencoba melakukan teknik mindfulness di luar sesi terapi. Melalui latihan mindfulness, ST menyadari tanda ketika dirinya mulai mengalami stress atau kelelahan. Melalui latihan loving and kindness meditation, ST mengungkapkan bahwa ia akan menggunakan teknik itu saat berada di situasi yang melelahkan karena ia dapat mengingat momen bahagia dan merasa lebih rileks. Ia menjadi lebih sadar bahwa dengan berolahraga, ia dapat melepaskan ketegangan yang dirasakan, sehingga ia ingin meningkatkan intensitas olahraga agar lebih sehat. Selanjutnya terkait dengan sesi harapan dan optimisme, ST mendapat tilikan bahwa meski terjadi banyak kesulitan selama bekerja, selalu ada harapan bahwa ia mampu mencari alternatif untuk mengatasi masalahnya itu.

\section{g. YE}

Setelah mengikuti sesi terapi kelompok, YE mendapat tilikan bahwa masalah merupakan hal yang wajar terjadi saat bekerja. Ia juga mulai menyadari kapan dirinya mengalami stress. Ketika ada masalah, ia mulai mengetahui bahwa ia bisa menarik napas terlebih dahulu agar lebih tenang dan selanjutnya bisa bercerita pada teman lain. Ia juga mendapat masukan dari teman-temannya bahwa self-care nya selama ini yaitu bermain games berlebihan dapat mengganggu pekerjaan dan aktivitasnya sehari-hari, dan kebiasaannya untuk menyendiri terlalu lama dapat membuatnya kesepian, sehingga lebih baik bercerita pada orang lain yang dianggap dapat dipercaya. Setelah seluruh sesi berakhir, YE juga merasa lebih tenang, meski sempat merasa pusing ketika sesi berlangsung. YE juga mengungkapkan bahwa melalui semua sesi terapi kelompok ini, ia belajar untuk mengendalikan diri saat dirinya marah dan bagaimana ia menyikapi sesuatu yang terjadi, baik itu kejadian baik atau buruk. Melalui latihan mindfulness, YE juga belajar untuk menyadari apa yang sedang ia lakukan, dan ia coba praktikkan dalam kegiatannya sebagai seorang asisten perawat

\section{h. YU}

Setelah mengikuti setiap sesi terapi kelompok ini, YU menyadari kondisi tubuhnya ketika stress dan mengetahui sumber stressnya. Ia merasa teknik mindfulness dapat digunakan untuk mengatasi stress, meski pada latihan pertama ia merasa tidak nyaman karena menyadari bahwa dirinya tidak baik-baik saja. YU mendapat tilikan bahwa aktivitas menonton drama Korea yang ia lakukan tidak dapat termasuk sebagai self-care karena dilakukan secara berlebihan dan membuatnya lupa dengan aktivitas harian hingga tidur larut malam. Ia mendapat masukan dari teman-temannya dan YU memutuskan untuk mengganti self-care nya dengan tidur atau mencari dukungan dari rekan kerja lainnya saat ia menemui kesulitan. Selain itu, YU mendapat tilikan pula bahwa terdapat peristiwa-peristiwa positif dalam hidupnya yang sebetulnya dapat membantunya untuk menghadapi stressor dan kelelahannya saat bekerja. 


\section{DISKUSI}

Berdasarkan hasil dari terapi kelompok ini, secara umum terdapat penurunan skor burnout pada peserta. Secara kualitatif, peserta juga mengungkapkan bahwa latihan-latihan mindfulness pada terapi MBSR ini membuat mereka merasa lebih tenang dan bermanfaat untuk mengurangi stress yang dirasakan. Hasil dari intervensi secara kualitatif juga menunjukkan bahwa ada peserta yang menyadari pentingnya bersikap mindful dalam kegiatan sehari-hari, terutama pada pekerjaannya. Hal ini sejalan dengan hasil penelitian sebelumnya bahwa terapi MBSR dapat membantu mengurangi stress dan meningkatkan kemampuan regulasi emosi dan dapat mengurangi tingkat burnout pada perawat (Shapiro, Astin, Bishop, \& Cordova, 2005; Shapiro dkk., 2007). Hasil dari intervensi secara kualitatif menunjukkan pula adanya kesesuaian dengan hasil penelitian bahwa adanya latihan teknik mindfulness dalam terapi MBSR juga dapat bermanfaat bagi perawat lansia untuk melatih kemampuan regulasi pikiran dan tingkah laku, meningkatkan kemampuan coping, motivasi, perencanaan, dan penyelesaian masalah; menjalani keseharian dengan lebih tenang; serta lebih fleksibel dalam menghadapi berbagai tantangan (Weare, 2014).

Pada hasil intervensi secara kuantitatif, diketahui bahwa dibandingkan dengan dimensi burnout lainnya, dimensi emotional exhaustion merupakan ciri yang paling banyak ditunjukkan oleh peserta, dilihat dari skor rata-ratanya yang paling tinggi. Saat hasil kuantitatif juga diketahui bahwa dimensi emotional exhaustion dan depersonalization mengalami penurunan setelah kegiatan terapi kelompok berakhir, tetapi reduced personal accomplishment tidak langsung mengalami penurunan saat diukur dengan post-test. Hasil ini berbeda dengan penelitian sebelumnya, ketika MBSR ini diberikan kepada perawat. Emotional exhaustion dan depersonalization mengalami penurunan dan terdapat peningkatan personal accomplishment yang juga memberikan intervensi MBSR (Adinda \& Bintari, 2020; Cohen-Katz, Wiley, Capuano, Baker, \& Shapiro dkk., 2005). Meski demikan, hasil ini sebetulnya sejalan dengan apa yang diungkapkan oleh Maslach dan Leiter (dalam Laschinger \& Fida, 2014) bahwa emotional exhaustion dan depersonalisasi merupakan ciri utama atau disebut sebagai inti dari kondisi burnout, meski konstruk burnout terdiri dari tiga dimensi. Keduanya merupakan representasi dari aspek kognitif dan afeksi dari burnout (Maslach, Schaufeli, \& Leiter, dalam Cheung, Tang, \& Tang, 2011). Kedua dimensi ini saling berkaitan erat, sehingga ketika diberikan intervensi tentang burnout, maka merupakan hal yang sangat wajar jika kedua dimensi inti ini yang mengalami perubahan yang sangat terlihat terlebih dahulu, karena ranah emosi dan afeksi lebih cepat untuk mengalami perubahan dibandingkan dengan perilaku. Sedangkan personal accomplishment sangat berkaitan dengan apakah individu memiliki berbagai sumber daya dan reward yang sepadan untuk membantunya menyelesaikan tugasnya (Maslach dkk., dalam Cheung dkk., 2011). Oleh karena itu, reduced personal accomplishment ini baru mengalami penurunan setelah dilakukan follow-up, dapat disebabkan oleh banyak faktor di luar sesi terapi kelompok, dan untuk perubahan perilaku yang menjadi tolak ukur dari dimensi ini membutuhkan waktu. Perubahan yang tidak signfikan ini juga dapat disebabkan oleh peserta belum merasakan perubahan mengenai sumber daya yang ia miliki untuk membantunya menyelesaikan berbagai tugasnya dengan baik. Selanjutnya ketika dilakukan followup test, diketahui bahwa skornya tidak jauh berbeda secara signifikan dibandingkan hasil post-test, menjadi indikasi bahwa perubahan yang terjadi pada peserta sudah mulai menetap.

Terkait dengan intervensi PCI, terutama pada terapi kelompok ini menyasar pada domain harapan dan optimisme, materi yang diberikan sampai pada tahap perubahan kognitif, satu tahap dalam teori belajar 
perilaku (Hoque, 2016). Pelatihan yang sudah dilaksanakan berisi pemaparan, yang ditujukan untuk meningkatkan pemahaman peserta bahwa kedua dimensi ini merupakan kapasitas diri yang penting dimiliki untuk melindungi mereka dari stress saat menghadapi situasi sulit. Peserta juga memahami berbagai aspek yang ada di dalam setiap domain PsyCap ini. Sesuai pula seperti model yang dibuat oleh Laschinger dan Fida (2014) bahwa PsyCap ini menjadi sumber dari dalam diri individu yang dapat menjadi faktor protektif dari kondisi burnout yang sangat mungkin dialami oleh perawat. Model ini pun sejalan dengan hasil penelitian bahwa keberadaan PsyCap menjadi kualitas diri yang menjadi sumber kekuatan individu dalam pekerjaannya sehingga dengan meningkatkan kualitas diri ini, dapat menurunkan tingkat burnout saat bekerja (Cheung et.al., 2011; Peng dkk., 2013) Secara khusus untuk kedua domain ini, semakin individu memiliki kualitas harapan, yang artinya ia memiliki kekuatan motivasional untuk menyelesaikan masalahnya, maka kualitas optimisme pada individu pun juga dapat meningkat (Luthans dkk., 2006). Pada dimensi harapan, berdasarkan hasil kualitatif, diketahui bahwa peserta dapat memahami ketika menghadapi situasi sulit, mereka perlu memiliki harapan terdapat berbagai alternatif yang dapat mereka lakukan untuk keluar dari masalah tersebut, sehingga tidak terjebak dengan situasi stress dan tingkat burnout menjadi turun (Luthans \& Jensen, 2002). Begitu pula dengan meningkatnya kesadaran individu bahwa kejadian negatif tidak selamanya ada di dalam hidup mereka, yang merupakan kualitas optimisme, maka individu pun juga tidak menjadi terus-menerus fokus pada situasi negatif, melainkan menyadari adanya kejadian positif yang bersifat lebih menetap dalam hidupnya (Seligman, dalam Hansen, Buitendach, \& Kanengoni, 2015).

Pelaksanaan terapi kelompok ini sedikit berubah dari rencana awal dari segi waktu pelaksanaan, peserta yang mengikuti kegiatan, dan beberapa kegiatan di dalam sesi. Hal ini dipengaruhi oleh faktor adanya peraturan social distancing oleh pemerintah karena pandemi Covid-19. Berdasarkan wawancara lanjutan dengan perawat panti, diketahui pula bahwa terdapat beberapa perubahan kondisi pegawai panti, paling tidak selama tiga bulan terakhir, terutama bagi perawat lansia karena adanya aturan izin keluar masuk asrama yang lebih ketat, berbagai protokol kesehatan yang harus dipatuhi, peraturan untuk menutup akses masuk dan keluar panti selama masa pandemi, dan kesulitan untuk memanggil dokter yang biasanya dapat mudah datang ke panti jika ada lansia yang butuh penanganan medis lebih lanjut. Tidak hanya itu, pengawasan terhadap kondisi kesehatan para lansia yang tinggal di panti pun menjadi lebih ketat. Berbagai perubahan ini kemudian disinyalir menjadi sumber stress juga bagi para perawat lansia di panti ini, yang dapat mengarah pada kondisi burnout. Hal ini pun sejalan dengan penelitian dari Barello, Palamenghi, dan Graffigna (2020) bahwa kondisi pandemi Covid-19 ini membuat semua pekerja di bidang kesehatan harus bekerja lebih keras dan menambah tekanan psikologis dan fisik bagi mereka, sehingga dapat menimbulkan burnout. Disebutkan pula bahwa selama pandemi ini berlangsung, tingkat emotional exhaustion menjadi aspek yang peningkatannya paling tampak dari para pekerja kesehatan, termasuk perawat (Barello dkk., 2020).

Penelitian ini cukup sederhana dan memiliki limitasi. Pertama, intervensi ini hanya diberikan kepada beberapa perawat lansia di satu panti werdha, sehingga hasil dari penelitian ini tidak cukup kuat untuk digeneralisasi pada populasi perawat lansia lainnya. Kedua, efektivitas hasil hanya dilihat dari penurunan skor burnout dari kuesioner CABUT dan wawancara pada peserta. Tidak dilakukan uji korelasi antara penurunan burnout dengan hasil dari harapan dan optimisme, sehingga tidak dapat dilihat seberapa besar proporsi penurunan burnout ini juga dipengaruhi oleh adanya intervensi harapan dan optimisme. 


\section{SIMPULAN}

Berdasarkan hasil kuantitatif, diketahui bahwa pemberian intervensi mampu menurunkan tingkat kecenderungan burnout pada peserta, terutama pada dimensi emotional exhaustion yang menjadi tanda bahwa terdapat kelelahan yang berlebihan secara fisik dan emosi pada peserta. Tidak hanya itu, sikap negatif terhadap pekerjaan juga berkurang setelah mengikuti kegiatan terapi kelompok ini. Tepat setelah kegiatan selesai, justru terdapat penurunan semangat dan produktivitas kerja. Akan tetapi setelah terdapat jeda selama dua minggu, terdapat indikasi peningkatan semangat dan produktivitas kerja kembali, dilihat dari hasil kuantitatifnya saat follow-up. Terkait dengan harapan dan optimisme, secara kuantitatif diketahui bahwa pemahaman peserta meningkat setelah diberikan sesi pemaparan materi. Peserta mampu memahami pentingnya memiliki harapan untuk mencari alternatif untuk penyelesaian masalah dan optimisme dalam bekerja untuk menjadi penguat diri mereka saat menghadapi situasi yang sulit. Peningkatan pemahaman secara objektif melalui pertanyaan seputar materi pun sejalan dengan meningkatnya pemahaman secara subjektif melalui self-rating. Berdasarkan hasil kualitatif, secara umum peserta merasakan perubahan ke arah yang lebih positif, mereka menjadi lebih mengenal dirinya, kondisi tubuhnya saat mengalami stress, sumber stressnya dan cara menanganinya. Selain itu hasil kualitatif menunjukkan bahwa mereka merasa latihan mindfulness mampu membuat diri mereka merasa lebih tenang, rileks, dan membantu mereka mengurangi stress. Akan tetapi, tetap perlu penelitian lanjutan untuk dapat mengatakan bahwa pemberian MBSR dan PsyCap ini benar-benar mampu memberikan perubahan yang signifikan bagi kondisi burnout perawat lansia di panti werdha.

\section{SARAN}

Penelitian ini menemukan bahwa setelah dilakukan intervensi MBSR dan PCI dengan menekankan pada psikoedukasi, terdapat penurunan skor burnout. Akan tetapi, pemberian intervensi untuk harapan dan optimisme baru sampai pada peningkatan kesadaran bagi peserta, sehingga saran untuk intervensi selanjutnya, pemberian PCI dilanjutkan hingga menyentuh ranah emosi dan perilaku agar manfaatnya dapat lebih dirasakan. Lalu pada setiap sesi, diberikan jeda yang lebih panjang antar sesi agar peserta memiliki waktu yang lebih panjang untuk meresapi materi dan dapat diberikan tugas pribadi untuk mengimplementasikan materi. Jika intervensi diperpanjang dan masih dalam situasi pandemi, dapat dipertimbangkan metode online dalam memberikan intervensi.

Terkait dengan limitasi dari penelitian ini, maka selanjutnya disarankan untuk membuat penelitian dengan adanya kelompok kontrol untuk melihat apakah penurunan burnout ini disebabkan oleh pemberian intervensi atau faktor lain. Kemudian penelitian juga dapat dilakukan di panti werdha lain, agar datanya dapat lebih merepresentasikan populasi perawat lansia. Terakhir, dapat dilakukan uji korelasi antara skor burnout dan pengukuran harapan dan optimisme untuk melihat apakah penurunan burnout juga disebabkan oleh adanya intervensi untuk meningkatkan harapan dan optimisme.

\section{DAFTAR PUSTAKA}

Adinda, R., \& Bintari, D. R. (2020). Mindfulness Based Stress Reduction (MBSR) group intervention to reduce burnout among caregivers in nursing home. Journal of Educational, Health, and Community Psychology, 9(2), 30-47.

Barello, S., Palamenghi, L., \& Graffigna, G. (2020). Burnout and somatic symptoms among frontliner healthcare professionals at the peak of the Italian COVID-19 pandemic. Psychiatry Research, 290, 1-4. 
Psychosomatic Research, 57(1), 35-

Chung, G. (2010). Nursing assistant beliefs about their roles and nursing home residents : Implications for nursing home social work practice. Social Work in Health Care, 49(8), 718733.

Cocco, E., Gatti, M., de Mendonça Lima, C. A., \& Camus, V. (2003). A comparative study of stress and burnout among staff caregivers in nursing homes and acute geriatric wards. International Journal of Geriatric Psychiatry, 18(1), 78-85.

Cohen-Katz, J., Wiley, S. D., Capuano, T., Baker, D. M., \& Shapiro, S. (2005). The effects of mindfulness-based stress reduction on nurse stress and burnout, Part II: A quantitative and qualitative study. Holistic Nursing Practice, 19(1), 26-35.

Cheung, F., Tang, C. S. K., \& Tang, S. (2011). Psychological capital as a moderator between emotional labor, burnout, and job satisfaction among school teachers in China. International Journal of Stress Management, 18(4), 348-371.

Cordes, C. L., Dougherty, T. W., \& Blum, M. (1997). Patterns of burnout among managers and professionals: A comparison of models. Journal of Organizational Behavior, 18(6), 685-701.

Grossman, P., Niemann, L., Schmidt, S., \& Walach, H. (2004). Mindfulnessbased stress reduction and health benefits: A meta-analysis. Journal of
43.

Hansen, A., Buitendach, J. H., \& Kanengoni, H. (2015). Psychological capital, subjective well-being, burnout and job satisfaction amongst educators in the Umlazi region in South Africa. SA Journal of Human Resource Management, 13(1), 1-9.

Hunt, C. K. (2003). Concepts in caregiver research. Journal of Nursing Scholarship, 35(1), 27-32.

Hoque, M. E. (2016). Three domains of learning : Cognitive, affective, and psychomotor. The Journal of EFL Education and Research, 2(2), 4552.

Iacovides, A., Fountoulakis, K.N., Kaprinis, S., \& Kaprinis, G. (2003). The relationship between job stress, burnout and clinical depression. Journal of Affective Disorders, 75, 209-221.

Kandelman, N., Mazars, T., \& Levy, A. (2018). Risk factors for burnout among caregivers working in nursing homes. Journal of Clinical Nursing, 27(1-2), 147-153.

Laschinger, H. K. S., \& Fida, R. (2014). New nurses burnout and workplace wellbeing: The influence of authentic leadership and psychological capital. Burnout Research, 1(1), 19-28.

Lee, R. T., \& Ashforth, B. E. (1990). On the meaning of Maslach's three dimensions of burnout. Journal of Applied Psychology, 75(6), 743-747. 
Leiter, M. P., \& Maslach, C. (2014). Interventions to prevent and alleviate burnout. In M. P. Leiter, A. B. Bakker, \& C. Maslach (Eds.), Current issues in work and organizational psychology. Burnout at work: A psychological perspective (p. 145-167). Psychology Press.

Luthans, F., Avey, J. B., Avolio, B. J., Norman, S. M., \& Combs, G. M. (2006). Psychological capital development: toward a microintervention. Journal of Organizational Behavior: The International Journal of Industrial, Occupational and Organizational Psychology and Behavior, 27(3), 387-393.

Luthans, F., \& Jensen, S. M. (2002). Hope : A new positive strength for human resource development. Human Resource Development Review, 1(3), 304-322.

Luthans, F., Youssef, C. M., \& Avolio, B. J. (2007). Psychological capital : Developing the human competitive edge. Oxford University Press.

Malinowski, P., \& Lim, H. J. (2015). Mindfulness at work: Positive affect, hope, and optimism mediate the relationship between dispositional mindfulness, work engagement, and well-being. Mindfulness, 6(6), 12501262.

Maslach, C., Jackson, S. E., \& Leiter, M. P. (1997). The Maslach Burnout Inventory manual (3rd ed.). Consulting Psychologist Press.
Maslach, C. \& Leiter, M. P. (2016). Understanding the burnout experience: Recent research and it's implication for psychiatry. World Psychiatry, 15(2), 103-111.

Okoye, U. O., \& Asa, S. S. (2011). Caregiving and stress: Experience of people taking care of elderly relations in South-Eastern Nigeria. Arts and Social Sciences Journal, 2011(29), 1-9.

Peng, J., Jiang, X., Zhang, J., Xiao, R., Song, Y., Feng, X., ... \& Miao, D. (2013). The impact of psychological capital on job burnout of Chinese nurses: The mediator role of organizational commitment. PloS One, 8(12), 1-7.

Shapiro, S. L., Astin, J. A., Bishop, S. R., \& Cordova, M. (2005). Mindfulnessbased stress reduction for health care professionals: Results from a randomized trial. International Journal of Stress Management, 12(2), 164-176.

Shapiro, S. L., Brown, K. W., \& Biegel, G. M. (2007). Teaching self-care to caregivers: Effects of mindfulnessbased stress reduction on the mental health of therapists in training. Training and Education in Professional Psychology, 1, 105115.

Snyder, C. R. (Ed.). (2000). Handbook of hope: Theory, measures, and applications. Academic Press.

Sherwin, E. D., Elliott, T. R., Rybarczyk, B. D., Frank, R. G., Hanson, S., \& Hoffman, J. (1992). Negotiating the 
reality of caregiving: Hope, burnout and nursing. Journal of Social And Clinical Psychology, 11(2), 129-139.

Waxman, H.M., Carner, E.A., \& Berkenstock, G. (1984). Job turnover and job satisfaction among nursing home aides. The Gerontologist, 24(5), 503-509.

Weare, K. (2014). Evidence for mindfulness: Impacts on the wellbeing and performance of school staff. Mindfulness in Schools Project, 1-23.

Widyanti, R. N., \& Bintari, D. R. (2010).

Gambaran kebahagiaan dan karakteristik positif perempuan dewasa madya yang menjadi caregiver informal penderita skizofrenia. Jurnal Ilmiah Psikologi MIND SET, 1(02), 110-117. 